\title{
Nephelometric Performance Evaluation of Oxidized Starch in the Treatment of Coal Washery Effluent
}

\author{
P. C. Nnaji ${ }^{*}$, B. I. Okolo ${ }^{1}$, M. C. Menkiti² \\ ${ }^{1}$ Chemical Engineering Department, Michael Okpara University of Agriculture, Umudike, Nigeria \\ ${ }^{2}$ Chemical Engineering Department, Nnamdi Azikiwe University, Awka, Nigeria \\ Email: ${ }^{*}$ nnaji_pat@yahoo.com
}

Received 2 January 2014; revised 5 February 2014; accepted 21 February 2014

Copyright (C) 2014 by authors and Scientific Research Publishing Inc.

This work is licensed under the Creative Commons Attribution International License (CC BY). http://creativecommons.org/licenses/by/4.0/

(c) (i) Open Access

\begin{abstract}
This study investigated the coag-flocculation performance of oxidized starch coagulant (OSC) and its blends with alum and $\mathrm{FeCl}_{3}$ in removing turbidity from coal washery effluent at room temperature. A conventional laboratory bench-scale jar test apparatus was employed for the experiments. Coag-flocculation parameters such as reaction order $\alpha$, rate constant $K$, coagulation time $\tau$, etc. were determined. The optimum $\mathrm{pH}$ was observed at 4.0 , while the blend of $30.0 \mathrm{mg} / \mathrm{L} \mathrm{FeCl}{ }_{3}$ and $250.0 \mathrm{mg} / \mathrm{L}$ OSC achieved the optimum turbidity removal. Turbidity removal efficiency was recorded between $96.0 \%$ and $\mathbf{9 9 . 9 \%}$ for various dosages and $\mathrm{pH}$ studied. The coagulation rate constants, $K$ recorded range from $9.393 \times 10^{-5} \mathrm{~L} / \mathrm{mg} \cdot \mathrm{min}$ to $8.294 \times 10^{-1} \mathrm{~min}^{-1}$, while coagulation periods $\tau$, range from $3.8 \mathrm{~s}$ to $235.7 \mathrm{~s}$ for various dosages and $\mathrm{pH}$ studied. The use of 0 SC blended with $\mathrm{FeCl}_{3}$ showed high level of efficiency, for the treatment of coal washery effluent.
\end{abstract}

\section{Keywords}

Oxidized Starch; Coal Washery Effluent; Coagulation/Flocculation; Jar Test

\section{Introduction}

Clarity of water is important towards manufacturing and products meant for human consumption. Turbidity in water is caused by suspended and colloidal matters such as clay, silts, finely divided organic and inorganic matter, plankton and other microorganisms [1].

The efficiency of suspended solid (colloid) separation from wastewater has been achieved by the application *Corresponding author. 
of coagulants like alum, ferric chloride, polyelectrolyte, etc. This process highlights a water treatment mechanism that stimulates the aggregation of suspended particles to settlable flocs by the destabilization of the charged colloids thus, neutralizing the forces that keep them apart. The factors that influence coag-flocculation are, among others, temperature, $\mathrm{pH}$, effluent quality, dosage and coagulant type [1]-[3].

The coag-flocculation process using inorganic coagulants has been well documented, but less attention has been given to the use of organic coagulant of plant origin like starch. However, the high cost, post usage handling and health issues associated with the inorganic coagulants have continued to pose serious challenges. Recently, researchers have shown interest in the use of natural organic derivative like Mucuna seed [4], Periwinkle shell [5], etc. for the treatment of waste water. This recent interest could be traced to the environmental friendliness of biocoag-flocculants. Biocoag-flocculants are non-toxic, natural and biodegradable [6] [7] and these made their application very promising.

In present work, cassava starch provides the focus of the study. Cassava starch is a natural, non toxic and biodegradable polymer. Chemically, starch is a hemopolymer made up of basically two molecular speciesamylopectin and amylase. While the amylase constitutes the inner part without any phosphorus, the amylopectin makes up the outer skin and contains combined species of phosphorus. Cassava starch is known to contain 17\% of amylase and 83\% amylopectin [8]. The oxidation of starch using calcium hypochlorite was employed. For effective turbidity removal, it has been found that the ratio of hypochlorite to starch should not be less than 2 and that the quantity of cassava starch per litre solution should not be more than $1 \mathrm{~g}$ [1]. Its application for treatment of wastewater can be extended to coal washery effluent.

Coal washery effluent wastewater has high suspended colloidal particle of mainly clay origin. It has an average initial turbidity of 23360.0NTU, pH of 2.68, TSS of $808.76 \mathrm{mg} / \mathrm{l}$, TDS of 449.232, alkalinity of $1.0 \mathrm{mg} / \mathrm{l}$ $\mathrm{CaCo}_{3}$ etc. (see Table 1).

This work therefore, demonstrated the effective application of OSC (Oxidized Starch Coagulant) for clarification of coal washery effluent. It further investigated the effect of dosage, $\mathrm{pH}$ as well as the blend of OSC. It also studied the process kinetics.

\section{Theoretical Background and Principles Development}

Turbidity is an expression of the optical property that causes light to be scattered and absorbed rather than transmitted with no change in direction or flux level through the sample [9].

Table 1. Results of coal wastewater effluent analysis.

\begin{tabular}{cc}
\hline Parameter & Coal Washery Effluent \\
\hline pH & 2.68 \\
Average initial turbidity(NTU) & $23,360.0$ \\
Alkalinity (mg/L CaCO $)$ & 1.0 \\
Electrical Conductivity (Microhms/cm) & 802.2 \\
Total Suspended Solids (mg/L) & 808.768 \\
Total Dissolved Solid (mg/L) & 449.232 \\
Calcium (mg/L) & 118.4 \\
Magnesium(mg/L) & 15.6 \\
Iron (mg/L) & 0.18 \\
Chloride (mg/L) & 184.34 \\
Sulphate (mg/L) & 65.6 \\
Nitrate (mg/L) & 0.15 \\
Chemical Oxygen Demand (mg/L) & 6468.0 \\
E-Coli (per 100 mL) & Nil \\
Total Coliform (per 100 mL) & Nil \\
Total plate count @35 ${ }^{\circ} \mathrm{C}$ after 24 hours(per mL) & 6.0 \\
\hline
\end{tabular}


Based on the work of Metcalf and Eddy [10], the relationship between turbidity and total suspended solid is as follows:

$$
\operatorname{TSS}(\mathrm{mg} / \mathrm{L})=\left(\mathrm{TSS}_{f}\right)(T)
$$

where TSS $=$ Total suspended solid, $\mathrm{mg} / \mathrm{L}$,

$\mathrm{TSS}_{f}=$ factor used to convert turbidity reading to total suspended solids $(\mathrm{mg} / \mathrm{L})$.

In the work of Menkiti et al., [11], it was shown that the coagulation rate constants could be determined by monitoring the changes in the turbidity of the coagulating liquid with time.

The time evolution of the cluster-size distribution for colloidal particles is usually described by the Smoluchowski Equation [12].

$$
\frac{\mathrm{d} C_{n}}{\mathrm{~d} t}=\frac{1}{2} \sum_{i+1} K_{i n} C_{i} C_{j}-C_{n} \sum_{i=1} K_{i n} C_{i}
$$

where $C_{n}(t)$ is the time dependent number concentration of n-fold cluster, $t$ is the time, and $K_{i j}$ are the elements of the rate kernel which control the rate of the coagulation between an $i$-fold and $j$-fold cluster.

Note that in the Smoluchowski analysis, the coagulation process is approximated to be entirely controlled by Brownian diffusion and initially having mono dispersed suspension. The implication of this is that the analysis attempts to quantitatively interpret the kinetics of rapid coagulation on the basis of diffusion (Brownian) motion of which is best studied during the early part (say $t<30 \mathrm{~min}$.) of coagulation process [4] [5] [13]-[15].

According to the work of Menkiti et al. [5], and Danov et al. [15], it was shown that the rate of depletion of particle count (TSS or turbidity removal) can be generally be represented as

$$
-\frac{\mathrm{d} C}{\mathrm{~d} t}=K C^{\infty}
$$

where $K$ is reaction rate constant, $C$ is the concentration and $\alpha$ is the order of reaction.

The generalized case of Equation (2) can be used to evaluate aggregation constant $K$ and order of the reaction $\alpha$ by taking [Ln] of both sides of the Equation (2).

$$
\ln \left(-\frac{\mathrm{d} C}{\mathrm{~d} t}\right)=\ln K+\alpha \ln C
$$

A plot of $\ln (-\gamma)$ versus $\operatorname{Ln} C$ gives a slope of $\alpha$ and intercept of $\operatorname{Ln} K$ from which $K$ is evaluated. Where

$$
\gamma=\frac{\mathrm{d} C}{\mathrm{~d} t} .
$$

For simple mono-dispersed aggregation model, the rate of coagulation can be found using Equations (1) and (2). The implication is that for Brownian controlled coagulation, Equations (1) and (2) are equal [5] [12] [16].

The process of aggregation is complex, and for the complicated particles, Equation (1) can be solved exactly to give generalized Equation (4):

$$
\frac{C_{i}}{C_{o}}=\frac{\left(t / \tau^{\prime}\right)^{i-1}}{\left(1+t / \tau^{\prime}\right)^{i+1}}
$$

where $\tau^{\prime}=2 \tau, \tau=1 / K C_{o}$ (period), $C_{i}=$ particles distribution concentration, $i=1$ (singlet), 2(doublet), 3(doublet).

From generalized Equation (4):

$$
\begin{aligned}
& C_{1}=\frac{C_{0}}{\left(1+t / \tau^{\prime}\right)^{2}} \\
& C_{2}=\frac{\left(t / \tau^{\prime}\right) C_{0}}{\left(1+t / \tau^{\prime}\right)^{3}} \\
& C_{3}=\frac{\left(t / \tau^{\prime}\right)^{2} C_{0}}{\left(1+t / \tau^{\prime}\right)^{4}}
\end{aligned}
$$




\section{Materials and Methods}

\subsection{Collection and Methods of Analyses of Coal Washery Effluent}

The coal washery effluent wastewater was collected during rainy season from moribund coal mine site, Enugu, Nigeria. The chemical oxygen demand was determined at the Regional Water Laboratory, Enugu. Other parameters were determined at Enugu State Water Corporation Laboratory. The $\mathrm{pH}$, electrical conductivity and turbidity were determined using Mettler Toledo Delta 320 pH Meter, EI Digital Conductivity Meter (model number 161) and EI Digital Turbidity Meter (model no. 337), respectively. The characterization result obtained and displayed in Table 1 was based on standard methods [9].

\subsection{Preparation of Coagulants Stock Solutions}

\subsubsection{Preparation of OSC}

Cassava starch was obtained from garri processing mill. Garri is a local food in Nigeria produced from cassava. The sludge obtained from milled cassava tubers was allowed to stand for $24 \mathrm{hr}$. After $24 \mathrm{hr}$, the solution separated into two layers. The upper layer was decanted, while the caked bottom was dried to become starch. A mixture of $1 \mathrm{~g}$ of cassava starch and $2 \mathrm{~g}$ of calcium hypochlorite was made into a solution with $100 \mathrm{~mL}$ of distilled water in a $1 \mathrm{~L}$ beaker. Distilled water of about $55^{\circ} \mathrm{C}$ was added to the solution to make it up to $1 \mathrm{~L}$. The solution was stirred for 15 mins using magnetic stirrer. The starch - hypochlorite solution was charged or electrolyzed for two hours to obtain OSC by passing direct current maintained between $0.1-0.2 \mathrm{~A}$ via an adapter. The voltage measured by digital meter across the electrode stood at 10.5 volts. The solution was constantly stirred using a magnetic stirrer maintained at $10 \mathrm{rpm}$ speed throughout the experiment.

\subsubsection{Preparation of Alum Solution}

$2.5 \mathrm{~g}$ of aluminum sulphate was weighed and dissolved in $100 \mathrm{~mL}$ of distilled water and made up to a liter to give $2.5 \mathrm{~g} / \mathrm{L}$ stock solution.

\subsubsection{Preparation of Ferric Chloride Solution}

$2.0 \mathrm{~g}$ of $\mathrm{FeCl}_{3} \cdot 6 \mathrm{H}_{2} \mathrm{O}$, was quickly weighed and dissolved in $100 \mathrm{~mL}$ of distilled water and made up to a liter to give $2.0 \mathrm{~g} / \mathrm{L}$ stock solution

\subsection{Jar Test}

The conventional jar test procedure was employed. 2 min of rapid mixing at $45 \mathrm{rpm}$ followed by 20 min of slow mixing at $15 \mathrm{rpm}$ was adapted. The volume of wastewater used was $500 \mathrm{~mL}$ for all the study. After stirring, the solution was carefully poured into $500 \mathrm{~mL}$ cylinder and allowed to settle for $30 \mathrm{mins}$. $20 \mathrm{~mL}$ of the clear upper layer of the settling solution was pipetted at $2 \mathrm{~cm}$ depth at 5 mins interval. The turbidity of these supernatants were measured and recorded. 50, 100, 150, $200 \mathrm{mg} / \mathrm{L}$ and $250 \mathrm{mg} / \mathrm{L}$ OSC were used. Furthermore, 10, 20, 30, 40, 50 and 100, 200, 300, 400, $500 \mathrm{mg} / \mathrm{L}$ of $\mathrm{FeCl}_{3}$ and alum, respectively were used.

\section{Results and Discussion}

\subsection{Coag-flocculation Performance Plots}

Jar test was conducted to determine the coag-flocculation performance of OSC and its blends with aim of obtaining the optimum $\mathrm{pH}$ and dosage.

The results of coag-flocculation performance of varying dosages (50 to $250 \mathrm{mg} / \mathrm{L}$ ) of OSC are presented in Figure 1. Figure 1 indicated that the minimum and the maximum removal of turbidity achieved was $98.2 \%$ for $100 \mathrm{mg} / \mathrm{L}$ OSC and $99.8 \%$ for $250 \mathrm{mg} / \mathrm{L}$ OSC, respectively.

Furthermore, it could be observed that turbidity removal increased from $98.2 \%$ at $100 \mathrm{mg} / \mathrm{L}$ to $99.8 \%$ at 250 $\mathrm{mg} / \mathrm{L}$ optimum dosage. This could be attributed to coag-flocculation mechanism of charge neutralization and inter particle bridging associated with high molecular weight polymer such as starch [17].

Coag-flocculation performances of OSC blended with $\mathrm{FeCl}_{3}$ and alum are presented in Figures 2-5. Figure 2 indicated that minimum and maximum turbidity removal were obtained for $50 \mathrm{mg} / \mathrm{L} \mathrm{FeCl}_{3} / 250 \mathrm{mg} / \mathrm{L}$ OSC and 


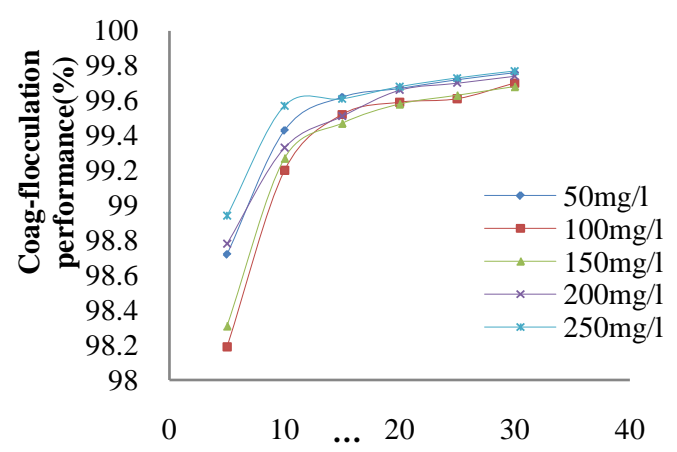

Figure 1. Coag-flocculation performance (\%) vs. time (min) for varying Oxidized Starch dosage only.

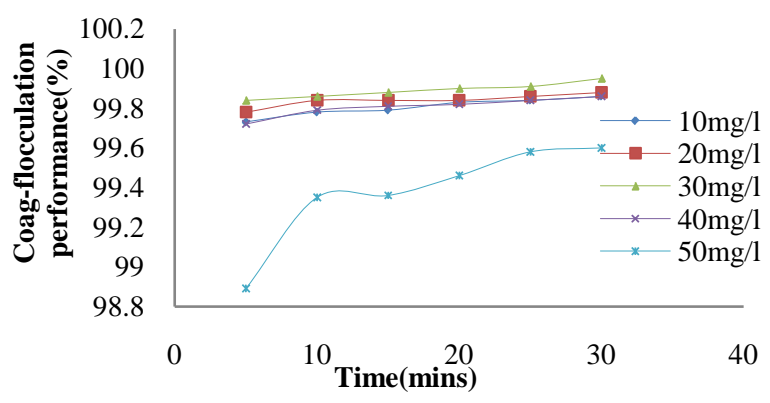

Figure 2. Coag-flocculation performance (\%) vs. time (min) for varying $\mathrm{FeCl}_{3}$ dosage at constant OSC dosage of 250 $\mathrm{mg} / \mathrm{L}$.

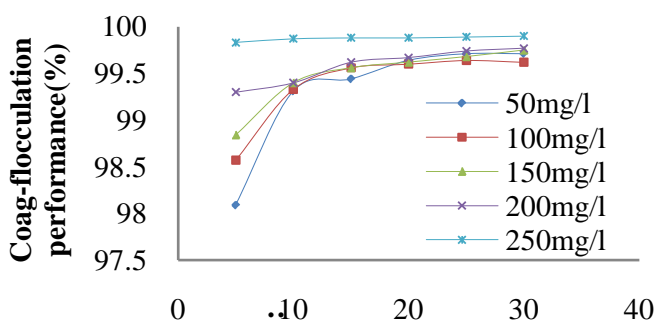

Figure 3. Coag-flocculation performance (\%) vs. time (min) for varying OSC dosage at constant $\mathrm{FeCl}_{3}$ dosage of $30 \mathrm{mg} / \mathrm{L}$.

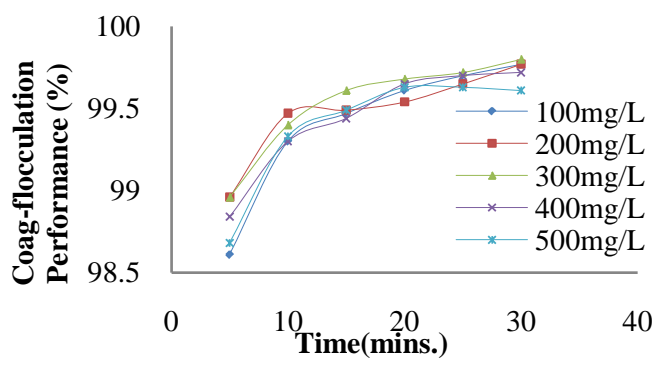

Figure 4. Coag-flocculation performance (\%) vs. time (min) for varying Alum at constant OSC dosage of $250 \mathrm{mg} / \mathrm{L}$.

$30 \mathrm{mg} / \mathrm{L} \mathrm{FeCl}_{3} / 250 \mathrm{mg} / \mathrm{L} \mathrm{OSC}$, at $98.9 \%$ and 99.95\%, respectively. For Figure 3, minimum (98.09\%) and maximum (99.9 \%) removal were achieved at $50 \mathrm{mg} / \mathrm{L} \mathrm{OSC} / 30 \mathrm{mg} / \mathrm{L} \mathrm{FeCl}$, and $250 \mathrm{mg} / \mathrm{L} \mathrm{OSC} / 30 \mathrm{mg} / \mathrm{L} \mathrm{FeCl}$, 


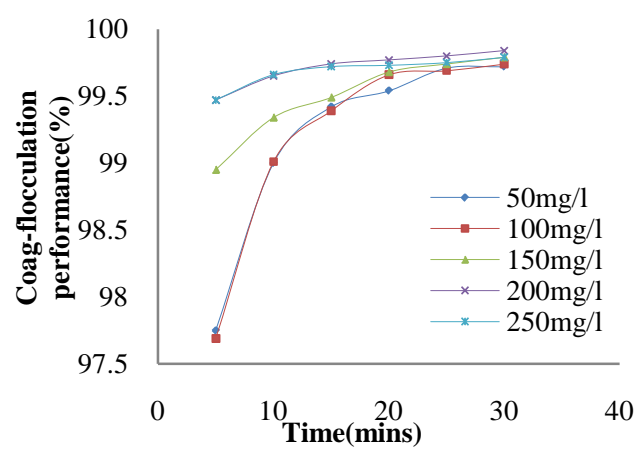

Figure 5. Coag-flocculation performance (\%) vs. time (min) for varying oxidized starch dosage at constant alum dosage of $300 \mathrm{mg} / \mathrm{l}$.

respectively.

Also, in Figure 4, minimum (98.6\%) and maximum (99.8\%), removal was obtained at $100 \mathrm{mg} / \mathrm{l}$ alum/250 mg/L OSC and $300 \mathrm{mg} / \mathrm{L}$ alum/250 mg/L OSC respectively. In Figure 5, minimum (97.69\%) and maximum (99.84\%), removal was achieved at $100 \mathrm{mg} / \mathrm{l} \mathrm{OSC/300} \mathrm{mg/L} \mathrm{alum} \mathrm{and} 200 \mathrm{mg} / \mathrm{L} \mathrm{OSC} / 300 \mathrm{mg} / \mathrm{L}$ alum, respectively.

Figure 3 indicates better performance with variation of OSC dose blended with $\mathrm{FeCl}_{3}$ dose when compared with variation of OSC dose only. The turbidity removal of the blend lies between $98.2 \%$ and $99.9 \%$. It was however, observed that this blend achieved $99.9 \%$ removal in $<10 \mathrm{~min}$ of coag-flocculation. This could not be unconnected with the sweep floc occasioned by charge neutralization and colloids entrapment due to precipitation of hydrous iron oxide. Inter particle bridging associated with OSC polymer also contributed to this high degree of aggregation. [17] [18]

Figure 5 showed minimum and maximum removal of 97.7 and $99.8 \%$ respectively, an indication of lower performance when compared with that of OSC blended with $\mathrm{FeCl}_{3}$. This was due to low $\mathrm{pH}$ value and alkalinity of the wastewater. These favour the formation of soluble $\mathrm{Al}^{3+}$ instead of $\mathrm{Al}(\mathrm{OH})_{3}$ which enhances coag-flocculation [17]. However, the relatively high total dissolved solids (TDS) of the wastewater resulting in high ionic strength, was a prelude to the enhanced turbidity removal obtained [19]. This agrees with the understanding that at high ionic strength (shown in Table 1), introducing a coag-flocculant like alum results in the reduction of the electrostatic repulsion between colloid particles, which led to efficient aggregation [6].

The results of coag-flocculation performance against dose were presented in Figure 6. The results indicate the effect of the coag-flocculation of OSC when blended with $\mathrm{FeCl}_{3}$ and alum. Also, it highlighted the optimum dosage and blend to be $250 \mathrm{mg} / \mathrm{LOSC}+30 \mathrm{mg} / \mathrm{L} \mathrm{FeCl}_{3}$.

Having obtained the optimum blend of $250 \mathrm{mg} / \mathrm{LOSC}+30 \mathrm{mg} / \mathrm{L} \mathrm{FeCl}_{3}$, the blend was further subjected to jar test at different $\mathrm{pH}$. The results are shown in Figure 7.

Figure 7 indicated that maximum and minimum removal of $99.9 \%$ and $98 \%$ for $\mathrm{pH}$ value of 4.0 and 10.0, respectively, were recorded.

This clearly highlighted the effect of $\mathrm{pH}$ in coag-flocculation, considering the fact that $\mathrm{pH}$ value determines the solubility and the type of $\mathrm{Fe}^{2+}$ or $\mathrm{Fe}(\mathrm{OH})_{2}$ formed. These in turn determine the charge of hydrous oxide complex, which affects the coag-flocculation process [1] [17]. The $\mathrm{pH}$ value of 4.0 favours the precipitation of $\mathrm{Fe}(\mathrm{OH})_{2}$, which coagulate by combination of sweep floc, charge neutralization and inter particle bridging [17].

Figure 8 indicated the coag-flocculation performance against $\mathrm{pH}$ value at different settling time. It also showed that the optimum $\mathrm{pH}$ of the process was 4 .

\subsection{Coag-flocculation Kinetics}

The results of graphical representation of Equation (3) were shown in Figures 9, 10, respectively. Using these Figures, the reaction order $\alpha$, coagulation rate constant $K$, and regression constant $R^{2}$ were determined and recorded in Tables 2, 3, respectively.

The results of varying OSC dose and its blends recorded in Table 2 and Figure 9 indicate first order reaction in all doses and blend. Also, Table 2 indicates variation in the coagulation time and rate constant despite the same order of reaction. The variation of rate constant was observed to be inversely proportional to coagulation 


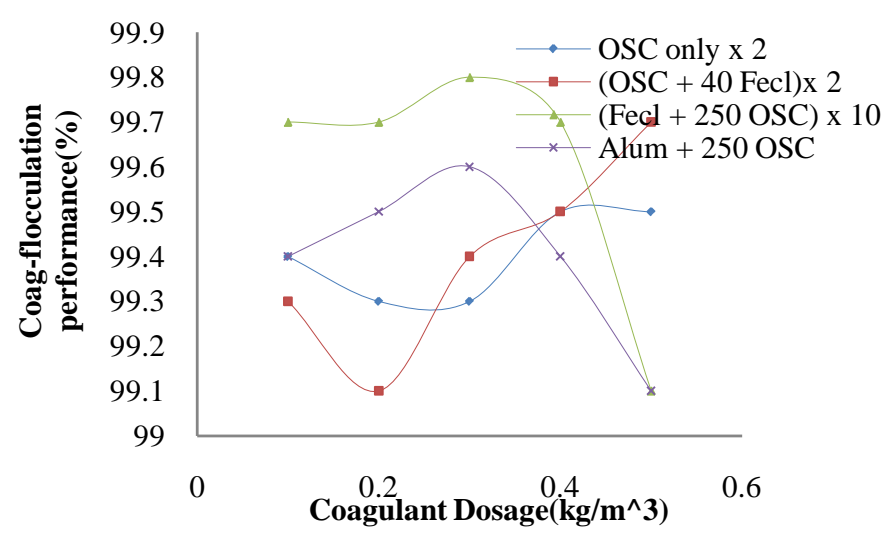

Figure 6. Coag-flocculation performance (\%) vs. coagulant dosage $(\mathrm{mg} / \mathrm{L})$ for OSC and its blends after 30 minute settling time

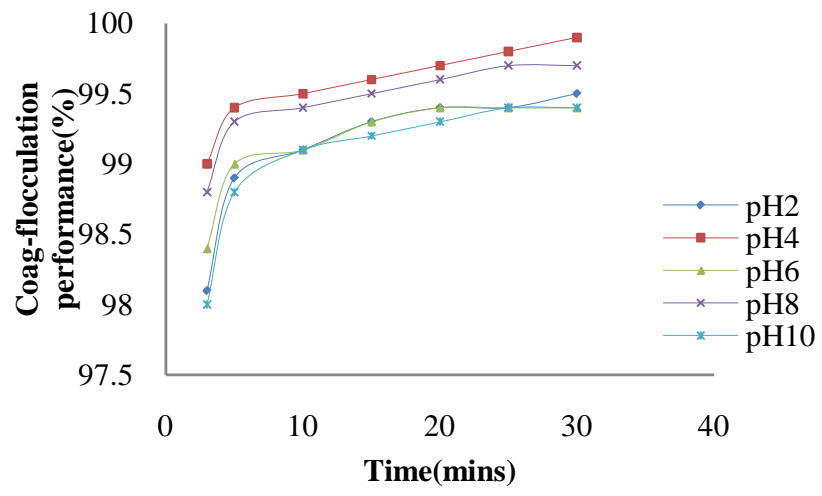

Figure 7. Coag-flocculation performance (\%) vs. Time (min) for optimum blend of $30 \mathrm{mg} / \mathrm{l} \mathrm{FeCl}_{3}+250 \mathrm{mg} / \mathrm{l} \mathrm{OSC}$ at different $\mathrm{pH}$ values.

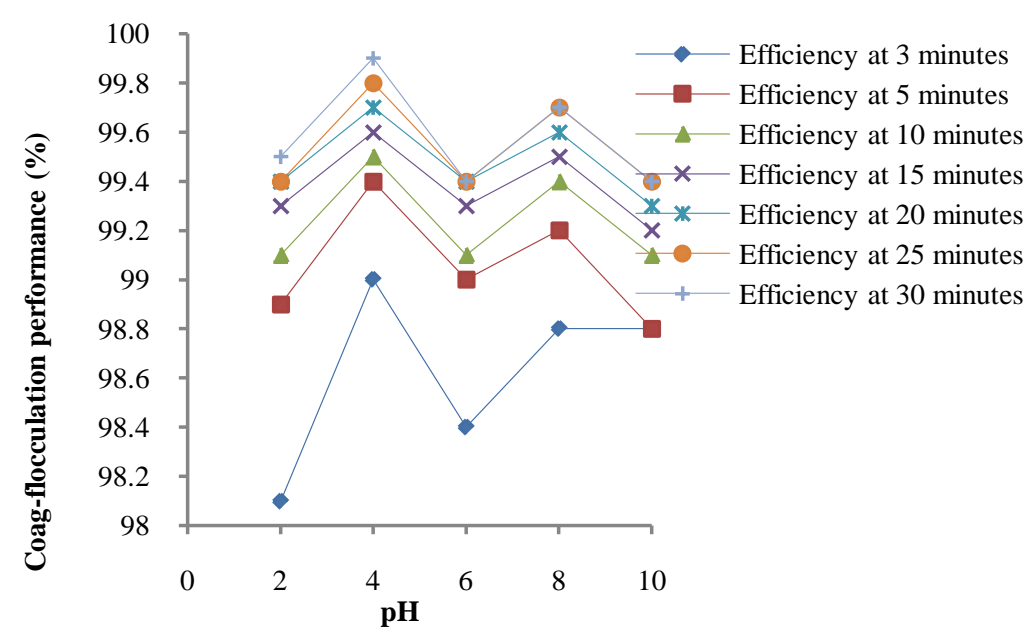

Figure 8. Coag-flocculation performance (\%) vs. $\mathrm{pH}$ for optimum blends of 30 $\mathrm{mg} / \mathrm{FeCl}_{3}+250 \mathrm{mg} / \mathrm{l} \mathrm{OSC}$ at different time interval. viz: Efficiency at 15, 20, 25 and 30 minutes.

time. This was invariably expected considering the relationship between the two parameters [20]. Table 2 also indicates that the lowest $K$ of $8.933 \mathrm{E} 3$ and the highest $\tau$ of $235.7 \mathrm{~s}$ was obtained with the blend of $250 \mathrm{mg} /$ LOSC and $40 \mathrm{mg} / \mathrm{L} \mathrm{FeCl}_{3}$, while the highest $K$ of $1.345 \mathrm{E} 2$ and the lowest $\tau$ of $51.6 \mathrm{~s}$ was obtained with the blend 


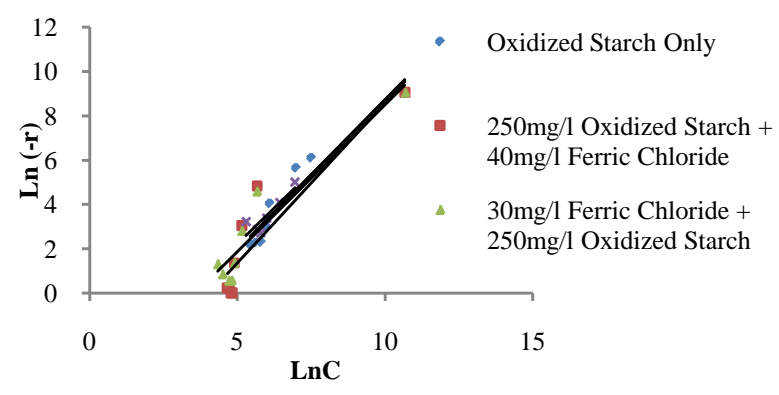

Figure 9. $\operatorname{Ln}(-r)$ vs. LnC for Oxidized Starch and its blends.

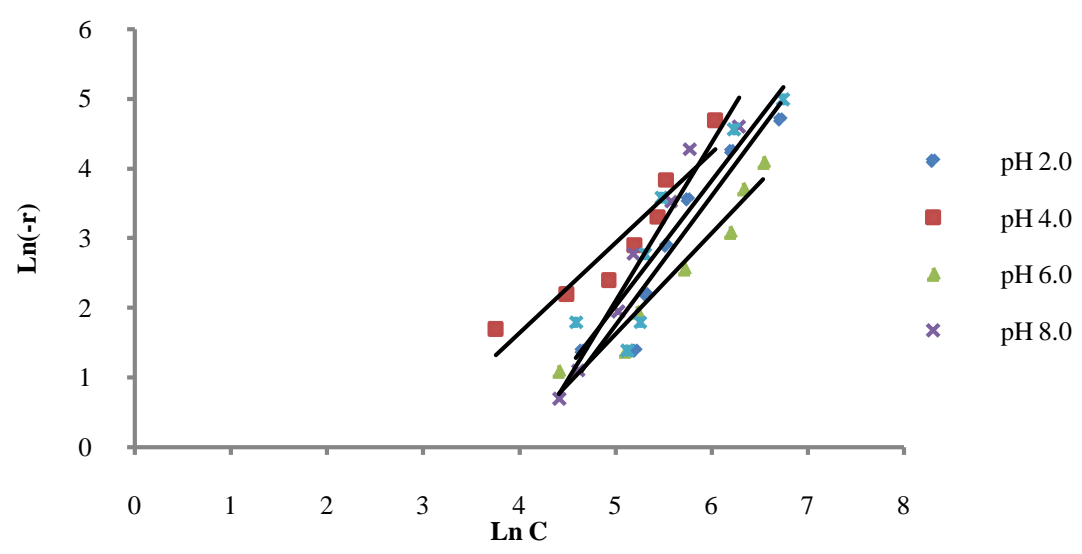

Figure 10. $\operatorname{Ln}(-r)$ vs. $\operatorname{LnC}$ for $\mathrm{pH}$ variation at optimum dosage.

Table 2. Coa-flocculation parameter for OSC and its blends.

\begin{tabular}{ccccc}
\hline $\begin{array}{c}\text { Parameter } \\
40 \mathrm{mg} / \mathrm{L} \mathrm{FeCl}_{3}\end{array}$ & $\begin{array}{c}\text { OSC only } \\
250 \mathrm{mg} / \mathrm{L} \text { OSC }\end{array}$ & $\begin{array}{c}250 \mathrm{mg} / \mathrm{L} \mathrm{OSC}+ \\
200 \mathrm{mg} / \mathrm{L} \mathrm{OSC}\end{array}$ & $30 \mathrm{mg} / \mathrm{L} \mathrm{FeCl}_{3}+$ & $300 \mathrm{mg} / \mathrm{L} \mathrm{Alum}+$ \\
$\alpha$ & 1 & 1 & 1 & 1 \\
$\mathrm{~K}\left(\mathrm{~min}^{-1}\right)$ & $8.059 \mathrm{E} 3$ & $2.941 \mathrm{E} 3$ & $8.933 \mathrm{E} 3$ & $1.345 \mathrm{E} 2$ \\
$\mathrm{R}^{2}$ & 0.918 & 0.836 & 0.893 & 0.783 \\
$\tau(\mathrm{s})$ & 86.0 & 235.7 & 77.6 & 51.6 \\
$-r(\mathrm{mg} / \mathrm{L} \cdot \mathrm{min})$ & $-r=8.059 \mathrm{E} 3 \mathrm{C}$ & $-r=2.941 \mathrm{E} 3 \mathrm{C}$ & $-r=8.933 \mathrm{E} 3 \mathrm{C}$ & $-r=1.345 \mathrm{E} 2 \mathrm{C}$ \\
\hline
\end{tabular}

Table 3. Coa-flocculation parameter for optimum blend (30 mg/L FeCl $3+250 \mathrm{mg} / \mathrm{L} \mathrm{OSC}$ ) at varying pH.

\begin{tabular}{cccccc}
\hline Parameter & $\mathrm{pH} 2.0$ & $\mathrm{pH} 4.0$ & $\mathrm{pH} 6.0$ & $\mathrm{pH} 8.0$ & 2 \\
\hline$\alpha$ & 2 & 1 & 1 & 2 \\
$K$ & $1.076 \mathrm{E} 2 \mathrm{~L} / \mathrm{mg} \cdot \mathrm{min}$ & $8.294 \mathrm{E} 1 \mathrm{~min}^{-1}$ & $3.628 \mathrm{E} 1 \mathrm{~min}^{-1}$ & $9.393 \mathrm{E} 5 \mathrm{~L} / \mathrm{mg} \cdot \mathrm{min}$ & $9.22 \mathrm{E} 4 \mathrm{~L} / \mathrm{mg} \cdot \mathrm{min}$ \\
$R^{2}$ & 0.907 & 0.891 & 0.947 & 0.964 & 21.3 \\
$\tau(\mathrm{s})$ & 3.80 & 23.9 & 185.8 & 5.2 \\
$-r(\mathrm{mg} / \mathrm{L} \cdot \mathrm{min})$ & $-r=1.076 \mathrm{E} 2 \mathrm{C}^{2}$ & $-r=8.294 \mathrm{E} 1 \mathrm{C}$ & $-r=3.628 \mathrm{E} 1 \mathrm{C}$ & $-r=9.393 \mathrm{E} 3 \mathrm{C}^{2}$ & $-r=9.22 \mathrm{E} 4 \mathrm{C}^{2}$ \\
\hline
\end{tabular}

$300 \mathrm{mg} / \mathrm{L}$ alum and $250 \mathrm{mg} / \mathrm{LOSC}$ [20].

Likewise, the results of coag-flocculation performance of optimum blend at varying $\mathrm{pH}$ were recorded in Table 3 and Figure 10, respectively. Coagulation Kinetic studied at $\mathrm{pH} 4$ and 6 proceeded by first order reaction, while that of $\mathrm{pH} 2,8$ and 10 agreed with second order reaction, respectively. The lowest $K$ of $9.393 \mathrm{E} 5$ and $\tau$ of 
$21.3 \mathrm{~s}$ was recorded at $\mathrm{pH}$ 8, while, the highest $K$ of 8.294E1 and $\tau=23.9 \mathrm{~s} \quad$ was recorded at $\mathrm{pH} 4$. These are in agreement with report recorded elsewhere [4] [19]. The values of $R^{2}$ for all the dosages and $\mathrm{pH}$ studied were sufficiently adequate. It revealed the effectiveness of Equations (2) and (3) in describing the coag-flocculation process [20].

\subsection{Particle Distribution Plot}

Equations (5) - (7) were used to predict the particle aggregation with time for varying OSC and its blends with alum and $\mathrm{FeCl}_{3}$. Also, the particle aggregation with time for varying $\mathrm{pH}$ using optimum blend was studied. The particle distribution $C_{1}, C_{2}$ and $C_{3}$ represent primary, secondary and tertiary particles, respectively. Figures 11-14 indicate similar trend in all the curves and represent the expected particle distribution in a typical low coagflocculation process [4] [19] [21].

Sharp primary particle aggregation occurred in $<5$ minutes of the process. This suggests instant but not continued charge neutralization and destabilization mechanism with low bridging.

Further look at the Figures 11-14 indicate low doublets and triplets. This is evident considering the fact that

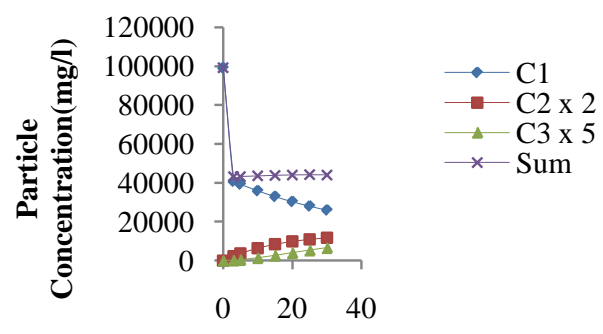

Time(mins.)

Figure 11. Particle distributions for varying OSC dosage from $50 \mathrm{mg} / \mathrm{l}$ to $250 \mathrm{mg} / \mathrm{l}$ for $\tau$ $=86.0 \mathrm{~s}$.

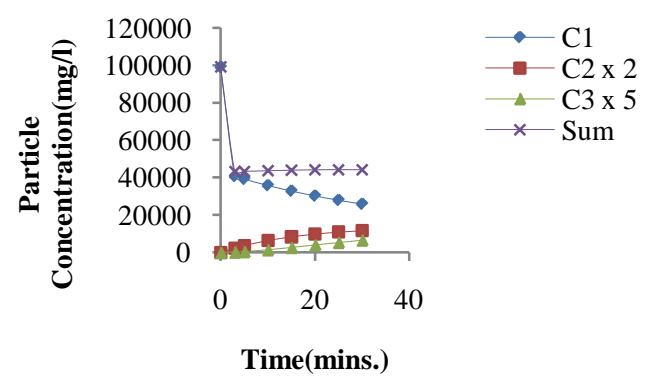

Figure 12. Particle distributions for varying $\mathrm{FeCl}_{3}$ from $10 \mathrm{mg} / \mathrm{l}$ to $50 \mathrm{mg} / \mathrm{l}$ at constant OSC of 250 $\mathrm{mg} / \mathrm{l}$ for $\tau=77.6 \mathrm{~s}$.

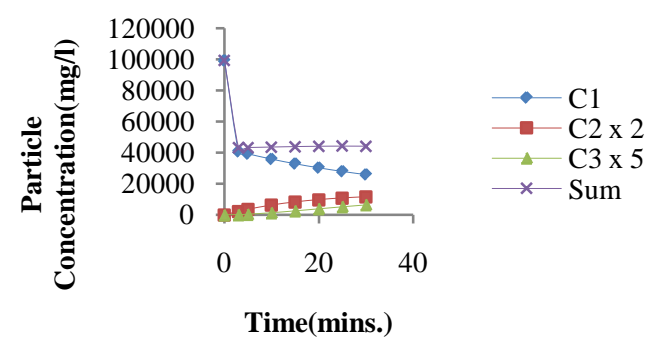

Figure 13. Particle distributions for varying alum from $100 \mathrm{mg} / \mathrm{l}$ to $500 \mathrm{mg} / \mathrm{l}$ at constant OSC of 200 $\mathrm{mg} / \mathrm{l}$ for $\tau=51.6 .0 \mathrm{~s}$. 


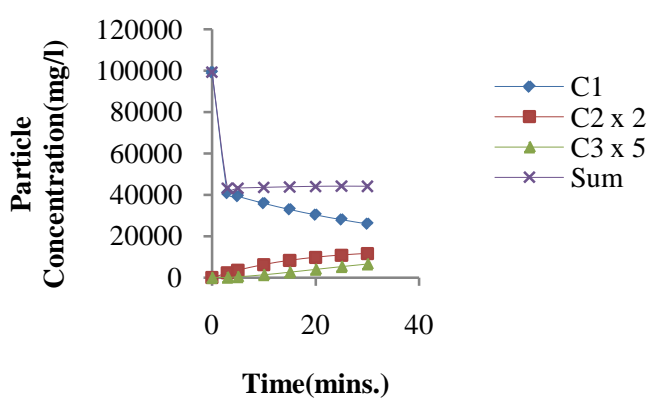

Figure 14. Particle distributions for optimum blend (30 mg/l $\mathrm{FeCl}_{3}+250 \mathrm{mg} / \mathrm{l} \mathrm{OSC}$ ) at $\mathrm{pH} 4$ for $\tau=$ $23.9 .0 \mathrm{~s}$.

doublets and triplets are formed by the charge neutralization and destabilization of singlet, though instant, but not massive.

\section{Conclusion}

From the present study, it can be concluded that OSC has the potential of biocoag-flocculant that could be applied in large scale water treatment, especially acidic water. This is supported by high turbidity removal efficiency range of $96 \leq \mathrm{E} \leq 99.9$. The optimum condition was observed with the blend of $250 \mathrm{mg} / \mathrm{L}$ OSC and 30 $\mathrm{mg} / \mathrm{L} \mathrm{FeCl}_{3}$ at $\mathrm{pH} 4$.

\section{References}

[1] Nnaji, P.C. (2012) An Investigation of the Performance of Various Coagulants/Flocculants in Removing the Turbidity of Coal Washery Effluents. M. Eng. Thesis, Federal University of Technology, Owerri.

[2] Jin, Y. (2005) Use of High Resolution Photographic Technique for Studying Coagulation/Flocculation in Water Treatment. M.Sc Thesis, University of Saskatchewan, Saskatoon, 22-29.

[3] Ma, J.J, Li, G.B, Chen, G.R., Xu, G.O and Cai, G.Q. (2001) Enhanced Coagulation of Surface Waters with High Organic Content by Permanganate Peroxidation. Water Science and Technology: Water Supply, 1, 51-61.

[4] Menkiti, M.C., Nnaji, P.C., Nwoye, O.D. and Onukwuli, O.D. (2010) Coa-Flocculation Kinetics and Functional Parameters Response of Mucuna Seed Coagulant to $\mathrm{pH}$ Variation in Organic Rich Coal Washery Effluent Medium. Journal of Mineral and Material Characterization and Engineering, 2, 89-103.

[5] Menkiti, M.C., Nnaji, P.C. and Onukwuli, O.D. (2009) Coa-Flocculation Kinetics and Functional Parameters Response of Periwinkle Shell Coagulant (PSC) to $\mathrm{pH}$ Variation in Organic Rich Coal Washery Effluent Medium. Nature and Science, 7, 1-18.

[6] Atkins, P.W. (1998) Physical Chemistry. 6th Edition, Oxford University Press, Oxford.

[7] Srinivasan, R. (2013) Simple, Efficient and Eco-Friendly Solution for Water and Wastewater Treatment. Blackland Research Center, Texas Agrilife Research, Texas A\&M University, Temple, Texas.

[8] Xie, S.X., Liu, Q. and Cui, S.W. (2005) Starch Modification and Applications. Taylor and Francis Group, LLC.

[9] AWWA, APHA and WEF (2012) Standard Methods for the Examination of Water and Wastewater. 22nd Edition, New York.

[10] Burton, F., Tchobanoglous, G. and Stensel, H.D. (2003) Physical Unit Process, Wastewater Engineering Treatment and Reuse. 4th Edition, McGraw Hill, New York.

[11] Menkiti, M.C., Osoka, E.C. and Onukwuli, O.D. (2008) Perikinetics Coagulation/Flocculation of Coal Washery Effluent Colloid with high Suspended Particle: Using Periwinkle Shell Coagulant (PSC). Journal of the Nigeria Society of Chemical Engineers, 23, 38-52.

[12] Von Smoluchowski, M. (1917) Versucheiner Mathematischen Theorie der Koagulation Kinetic Kolloide Lousungen Z. The Journal of Physical Chemistry, 92, 129-168

[13] Maiti, S.K., Karmakar, N.C. and Sharrna, P. (2004) Study on Settling Behavior of Coal Washery Effluent-A Case Study. Proceedings of the National Seminar on Environmental Engineering with Special Emphasis on Mining Environment, NSEEME-2004, Dhanbad, 19-20 March 2004, 187-192. 
[14] Van Zanten, J.H., and Elimelechi, M. (1992) Determination of Rate Constants by Multi Angle Light Scattering. Journal of Colloid and Interface, 154, 1-7. http://dx.doi.org/10.1016/0021-9797(92)90072-T

[15] Water Specialist Technology (WST) (2005) About Coagulation and Flocculation. Information Bulletins, USA.

[16] Danov, D.K., Kralchevsky, P.A. and Ivanov, I.B. (2001) Dynamics Process in Surfactants Stabilized Emulsion. Faculty of Chemistry, University of Sofia, Sofia.

[17] Ravina, L. (1973) Everything You Want to Know about Coagulation and Flocculation. 4th Edition, Zeta-Meter Inc., Staunton.

[18] B. Bina, Mehdinejad, M.H., Nikaeen, M. and Movahedian Attar, H. (2009) Effectiveness of Chitosan as Natural Coagulant Aid in Treating Turbid Waters, Iran. Journal of Environmental Health Science and Engineering, 6, 247-252

[19] Ani, J.U., Nnaji, N.J.N., Onukwuli, O.D. and Okoye, C.O.B. (2012) Nephelometric and functional parameters response of coagulation for the purification of industrial wastewater using Detarium microcarpum. Journal of Hazardous Materials, 243, 59-66,

[20] Fogler, H.S. (2012) Elements of Chemical Reaction Engineering. 4th Edition, PHI Learning Private Ltd, New Delhi.

[21] Menkiti, M.C. and Onukwuli, O.D. (2011) Single and Multi Angle Nephelometric Approach to the Study of CoagFlocculation of Coal Washery Effluent Medium using Brachystegia Eurycoma Coagulant (BEC). World Journal of Engineering, 8, 61-76. http://dx.doi.org/10.1260/1708-5284.8.1.61 